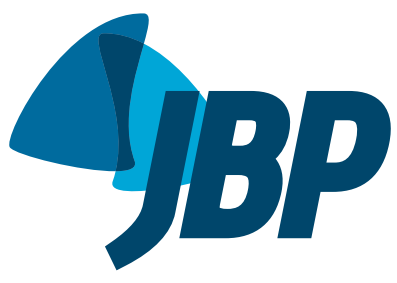

1. Departamento de Saúde Pública, Universidade Federal de Santa Catarina, Florianópolis (SC) Brasil.

2. Johns Hopkins Bloomberg School of Public Health, Baltimore (MD) USA.

3. Institute for Global Tobacco Control, Johns Hopkins Bloomberg School of Public Health, Baltimore (MD) USA.

a. (iD) http://orcid.org/0000-0002-4531-6602

b. (iD) http://orcid.org/0000-0001-9331-1550

c. (iD http://orcid.org/0000-0002-9163-1005

Submitted: 9 May 2017.

Accepted: 15 October 2017.

Study carried out in the Departamento de

Saúde Pública, Universidade Federal de

Santa Catarina, Florianópolis (SC) Brasil.

\section{Association between the display of cigarette packs at the point of sale and smoking susceptibility among adolescents in Brazil}

\author{
Ana Luiza Curi Hallal', Andreza Madeira Macario', Roberto Hess de Souza2,a,
} Antônio Fernando Boing ${ }^{1, b}$, Lúcio Botelho ${ }^{1, c}$, Joanna Cohen ${ }^{3}$

\begin{abstract}
This was a cross-sectional study aimed at determining the association between exposure to tobacco displays at the point of sale and susceptibility to smoking in schoolchildren in the 14- to 17-year age bracket. Of the participating students, $69.0 \%, 21.3 \%$, and $9.7 \%$ were classified as never smokers, experimenters, and smokers, respectively. Of the participants who were classified as being exposed to smoking, $18.9 \%$ were susceptible to smoking. Of the participants who were classified as being unexposed to smoking, $12.9 \%$ were susceptible to smoking (OR $=1.56 ; 95 \% \mathrm{Cl}: 1.04-2.35 ; \mathrm{p}=0.029$ ). Exposure to point-of-sale tobacco displays is associated with smoking susceptibility in Brazilian adolescents.
\end{abstract}

Keywords: Tobacco products; School health; Adolescent health.
Smoking is the most common cause of preventable death in the world, given that it increases the risk of death from diseases such as cancer, ischemic heart disease, and COPD. ${ }^{(1)}$ In Brazil, the prevalence of smoking in the adult population has decreased in recent decades. ${ }^{(2,3)}$ Data collected by the Brazilian National Ministry of Health Department of Health Surveillance using telephone-based survey methods show a reduction in the prevalence of adult smokers in Brazil, from 15.6\% in 2006 to $11.3 \%$ in 2013. ${ }^{(3)}$

This downward trend in the prevalence of smoking among adults in Brazil has not been observed in young Brazilians. ${ }^{(4)}$ The Pesquisa Nacional de Saúde do Escolar (PeNSE, Brazilian National Adolescent School-Based Health Survey), conducted over several years, showed that the prevalence of young individuals who reported having smoked in the 30 days preceding the survey had not decreased, having remained at approximately $6.0 \%$. $^{(4)}$

In Brazil, several strategies have been implemented to reduce tobacco supply and demand, including public policies toward tobacco advertising, promotion, and sponsorship, as well as toward health warnings, passive smoking, smoking cessation treatment, illegal tobacco trade, prices, and taxes. ${ }^{(2,5)}$ With regard to laws aimed at protecting the population from exposure to tobacco advertising, Federal Law no. $10,167 / 2000^{(6)}$ banned the advertising of tobacco products in magazines and newspapers, as well as on television, radio, and billboards. It also banned Internet-based tobacco advertising, indirect advertising, and advertising in stadiums, at race tracks, on stages, and in other similar places; in addition, as of 2003, it banned tobacco-company sponsorship of international sporting events and cultural events. Federal Law no. 12,546/2011, regulated by Decree no. 8,262/2014, banned the advertising of tobacco products at the point of sale, representing a significant advance in the national legislation; however, the display of tobacco products at the point of sale is still allowed in the country. ${ }^{(7,8)}$

The tobacco industry has implemented several strategies to counter tobacco advertising bans, including increasingly sophisticated tobacco displays, attractive packaging, and preferred positions in displays at the point of sale, i.e., near products that are attractive to children and young individuals. ${ }^{(9)}$

In this context, the objective of the present study was to determine the association between the display of cigarette packs at the point of sale and smoking susceptibility among Brazilian adolescents.

We conducted a cross-sectional study involving a sample of high school students who were in the 14- to 17-year age bracket and who attended state public schools in the morning in any of five Brazilian capitals (i.e., Brasília, São Paulo, Manaus, Curitiba, and Salvador). All of the students who met the inclusion criteria and who attended class on the day assigned for data collection were invited to participate in the study. Data were collected by means of an anonymous self-administered questionnaire that was completed under the supervision of a trained field team.

The study variables were as follows: gender; age; high school grade level; parental smoking; respondent smoking status; exposure to smoking; susceptibility

Correspondence to:

Ana Luiza Curi Hallal. Departamento de Saúde Pública, Centro de Ciências da Saúde, Universidade Federal de Santa Catarina, Rua Eng. Agronômico Andrei

Cristian Ferreira, s/n, Trindade, CEP 88040-900, Florianópolis, SC, Brasil.

Tel.: 5548 3721-6359. E-mail: anacuri@gmail.com

Financial support: This study received financial support from the Institute for Global Tobacco Control at the Johns Hopkins Bloomberg School of Public Health. 
to smoking in the year following study participation; and exposure to tobacco displays and advertising at the point of sale (including bakeries, minimarkets, convenience stores, and supermarkets).

Nonsmoking schoolchildren who reported that they would probably or definitely start smoking in the following year were classified as susceptible to smoking. ${ }^{(10,11)}$ Schoolchildren who reported that they frequented at least one of the aforementioned points of sale and saw cigarette packs displayed there were classified as being exposed to smoking. Schoolchildren who reported that they did not frequent any of the aforementioned points of sale or see cigarette packs displayed there were classified as being unexposed to smoking. Schoolchildren who reported having smoked at least once in the 30 days preceding the survey were classified as smokers.

We used Pearson's chi-square test in order to identify associations among independent variables, values of $p<0.05$ being considered statistically significant.

The study was approved by the Research Ethics Committee of the Federal University of Santa Catarina, located in the city of Florianópolis, Brazil (Ruling no. $552,940)$, and by the Johns Hopkins School of Public Health Institutional Review Board, located in the city of Baltimore (MD) USA (Protocol no. 00005015).

We interviewed 11,086 schoolchildren, 5,964 (53.8\%) of whom were female. The participating students were classified as never smokers, experimenters, or smokers. The proportions of never smokers, experimenters, and smokers in the study sample were $69.0 \%, 21.3 \%$, and $9.7 \%$, respectively.

The prevalence of smoking in the present study (9.7\%; 95\% CI: 9.4-10.5) was higher than that in the 2012 PeNSE, ${ }^{(12)}$ in which 5.1\% (95\% CI: 3.9-6.2) of students in 27 Brazilian capitals (including the Federal District of Brasília) were identified as being regular smokers. This difference in the prevalence of smoking might be due to methodological differences between the present study, which included public high school students in the 14- to 17-year age bracket, and the PeNSE, which included 9th-grade students at public and private schools in Brazil.(12)

A total of 3,407 students (30.7\%) responded in the affirmative to the question "Have you ever tried or experimented with cigarette smoking, even one or two puffs?" Of the students who were classified as experimenters or smokers, $10.3 \%$ had smoked their first full cigarette before the age of 10 years.

Questions regarding the habit of frequenting points of sale showed that the vast majority of students (98.9\%) had frequented at least one of the aforementioned points of sale during the study period, virtually all of the participants $(99.2 \%)$ having reported viewing point-of-sale tobacco displays (Table 1 ).

Of the male participants, $67.9 \%$ had never smoked, $21.3 \%$ had tried cigarettes, and $10.8 \%$ were smokers. Of the female participants, $69.9 \%$ had never smoked, $21.1 \%$ had tried cigarettes, and $9.0 \%$ were smokers (Table 2).

Of the participants who were classified as being exposed to smoking, $18.9 \%$ were susceptible to smoking. Of the participants who were classified as being unexposed to smoking, $12.9 \%$ were susceptible to smoking. A significant association was found between exposure to point-of-sale tobacco displays and smoking susceptibility (OR $=1.56 ; 95 \% \mathrm{CI}$ : 1.04-2.35; $\mathrm{p}=0.029$ ).

In a study conducted in the United Kingdom in 2008 and involving young individuals in the 11- to 16-year age bracket, Mackintosh et al.(13) reported that the proportion of individuals who were exposed to tobacco displays was high (i.e., $81.0 \%$ ), having also found a significant association between exposure to point-ofsale tobacco displays and smoking susceptibility (OR $=1.77 ; 95 \%$ CI: 1.15-2.73; $p=0.029$ ).

Other studies have found that children and adolescents who are exposed to point-of-sale tobacco displays are more likely to be susceptible to smoking. ${ }^{(14-16)}$ In a recently published systematic review aimed at examining the relationship between promotion of tobacco products at the point of sale and susceptibility to smoking, the authors concluded that current evidence supports a positive association between the two. ${ }^{(16)}$

One limitation of the present study is that it is representative of adolescents who attended state public schools in the morning in any of five Brazilian capitals and who attended class on the day assigned for data collection.

In conclusion, exposure to point-of-sale tobacco displays is associated with smoking susceptibility in Brazilian adolescents. The findings of the present study reinforce the importance of banning tobacco displays at the point of sale.

Table 1. Numbers and proportions of schoolchildren classified as never smokers, experimenters, or smokers on the basis of their answers to questions regarding visits to tobacco points of sale and exposure to tobacco displays at the point of sale. Brazil, 2014.

\begin{tabular}{|c|c|c|c|c|}
\hline \multirow[t]{3}{*}{ Smoking status } & \multicolumn{4}{|c|}{ Questionnaire item } \\
\hline & \multicolumn{2}{|c|}{$\begin{array}{c}\text { Frequents at least one tobacco point of } \\
\text { sale }\end{array}$} & \multicolumn{2}{|c|}{$\begin{array}{c}\text { Frequents a tobacco point of sale and } \\
\text { sees tobacco displays there }\end{array}$} \\
\hline & $\mathbf{n}$ & $\%$ & $\mathbf{n}$ & $\%$ \\
\hline Never smokers & 7,561 & 98.9 & 7,561 & 100.0 \\
\hline Experimenters & 2,317 & 99.3 & 2,278 & 98.8 \\
\hline Smokers & 1,076 & 98.1 & 1,051 & 97.9 \\
\hline TOTAL & 10,954 & 98.9 & 10,961 & 99.2 \\
\hline
\end{tabular}


Table 2. Numbers and proportions of schoolchildren, by gender, grade, age, and smoking status. Brazil, 2014.

\begin{tabular}{|c|c|c|c|c|c|c|c|c|}
\hline \multirow[t]{3}{*}{ Variable } & \multicolumn{6}{|c|}{ Smoking status } & \multirow{2}{*}{\multicolumn{2}{|c|}{ Total }} \\
\hline & \multicolumn{2}{|c|}{ Never smoker } & \multicolumn{2}{|c|}{ Experimenter } & \multicolumn{2}{|c|}{ Smoker } & & \\
\hline & $\mathbf{n}$ & $\%$ & $\mathbf{n}$ & $\%$ & $\mathbf{n}$ & $\%$ & $\mathbf{n}$ & $\%$ \\
\hline Male gender & 3,285 & 67.9 & 1,030 & 21.3 & 520 & 10.8 & 4,835 & 100.0 \\
\hline Female gender & 4,143 & 69.9 & 1,247 & 21.1 & 533 & 9.0 & 5,923 & 100.0 \\
\hline \multicolumn{9}{|c|}{ High school grade level } \\
\hline 1 & 4,267 & 70.5 & 1,175 & 19.4 & 607 & 10.0 & 6,049 & 100.0 \\
\hline 2 & 2,115 & 67.0 & 710 & 22.5 & 332 & 10.5 & 3,157 & 100.0 \\
\hline 3 & 1,052 & 66.5 & 399 & 25.2 & 132 & 8.3 & 1,583 & 100.0 \\
\hline \multicolumn{9}{|l|}{ Age, years } \\
\hline 14 & 375 & 73.5 & 69 & 13.5 & 66 & 12.9 & 510 & 100.0 \\
\hline 15 & 2,491 & 74.0 & 612 & 18.2 & 263 & 7.8 & 3,366 & 100.0 \\
\hline 16 & 2,474 & 67.3 & 804 & 21.9 & 398 & 10.8 & 3,676 & 100.0 \\
\hline 17 & 2,069 & 64.5 & 797 & 24.8 & 343 & 10.7 & 3,209 & 100.0 \\
\hline
\end{tabular}

\section{REFERENCES}

1. Eriksen M, Mackay J, Schluger N, Gomeshtapeh FI, Drope J. The tobacco atlas. 5th ed. Atlanta: American Cancer Society; 2015.

2. Monteiro CA, Cavalcante TM, Moura EC, Claro RM, Szwarcwald $\mathrm{CL}$. Population-based evidence of a strong decline in the prevalence of smokers in Brazil (1989-2003). Bull World Health Organ. 2007;85(7):527-34. https://doi.org/10.2471/BLT.06.039073

3. Malta DC, Oliveira TP, Luz M, Stopa SR, da Silva Júnior JB, dos Reis AA. Smoking trend indicators in Brazilian capitals, 2006-2013. Cien Saude Colet. 2015;20(3):631-40. https://doi.org/10.1590/141381232015203.15232014

4. Malta DC, de Andrezzi MA, Oliveira-Campos M, Andrade SS, de Sá NN, de Moura L, Dias AJ, et al. Trend of the risk and protective factors of chronic diseases in adolescents, National Adolescent School-based Health Survey (PeNSE 2009 e 2012). Rev Bras Epidemiol. 2014;17 Suppl 1:77-91. https://doi.org/10.1590/18094503201400050007

5. Iglesias R, Jha P, Pinto M, Costa e Silva VL, Godinho J. Controle do tabagismo no Brasil. Washington DC: World Bank; 2007.

6. Brasil. Ministério da Casa Civil. Subchefia para Assuntos Jurídicos [homepage on the Internet]. Lei no. 10.167, de 27 de dezembro de 2000; [about 4 screens]. Available from: http://www. planalto.gov.br/ ccivil_03/leis/L10167.htm

7. Brasil. Ministério da Casa Civil. Subchefia para Assuntos Jurídicos [homepage on the Internet]. Lei no. 12.546, de 14 de dezembro de 2011; [about 140 screens]. Available from: http://www.planalto.gov. br/CCIVIL_03/_Ato2011-2014/2011/Lei/L12546.htm

8. Brasil. Ministério da Casa Civil. Subchefia para Assuntos Jurídicos [homepage on the Internet]. Decreto no. 8.262, de 31 de maio de
2014; [about 4 screens]. Available from: http://www.planalto.gov.br/ ccivil_03/_Ato2011-2014/2014/Decreto/D8262.htm

9. Pantani D, Pinsky I, Monteiro A. Publicidade de tabaco no ponto de venda. São Paulo: Editora do Autor; 2011.

10. Pierce JP, Choi WS, Gilpin EA, Farkas AJ, Merritt RK. Validation of susceptibility as a predictor of which adolescents take up smoking in the United States. Health Psychol. 1996;15(5):355-61. https://doi. org/10.1037/0278-6133.15.5.355

11. Unger JB, Johnson CA, Stoddard JL, Nezami E, Chou CP (1997). Identification of adolescents at risk for smoking initiation: validation of a measure of susceptibility. Addict Behav. 1997;22(1):81-91. https://doi.org/10.1016/0306-4603(95)00107-7

12. Brasil. Instituto Brasileiro de Geografia e Estatística (IBGE). Pesquisa Nacional de Saúde Escolar (PeNSE), 2012. Rio de Janeiro: IBGE 2012.

13. Mackintosh AM, Moodie C, Hastings G. The association between point-of-sale display and youth smoking susceptibility. Nicotine Tob Res. 2012;14(5);616-20. https://doi.org/10.1093/ntr/ntr185

14. Paynter J, Edwards R. The impact of tobacco promotion at the point of sale: a systematic review. Nicotine Tob Res. 2009;11(1);25-35. https://doi.org/10.1093/ntr/ntn002

15. Paynter J, Edwards R, Schluter PJ, McDuff I. Point of sale tobacco displays and smoking among 14-15 year olds in New Zealand: a cross-sectional study. Tob Control. 2009;18(4):268-74. https://doi. org/10.1136/tc. 2008.027482

16. Robertson L, McGee R, Marsh L, Hoek J. A systematic review on the impact of point-of-sale tobacco promotion on smoking. Nicotine Tob Res. 2015;17(1):2-17. https://doi.org/10.1093/ntr/ntu168 